\title{
Water saving $v s$. farm economics in cotton surface irrigation: An application of multicriteria analysis
}

\author{
Hanaa Darouich ${ }^{\mathrm{a}, \mathrm{b}}$, José M. Gonçalves ${ }^{\mathrm{a}}$, André Muga ${ }^{\mathrm{a}}$, Luis S. Pereira ${ }^{\mathrm{a}, *}$ \\ a CEER - Biosystems Engineering, Institute of Agronomy, Technical University of Lisbon, Portugal \\ b General Commission for Scientific Agriculture Research (GCSAR), Damascus, Syria
}

\section{A R T I C L E I N F O}

\section{Article history:}

Received 15 May 2012

Accepted 11 September 2012

\section{Keywords:}

Furrow and border irrigation

Economic water productivity

Land leveling

Deficit irrigation

Decision support systems

Model SADREG

Northeast Syria

Khabour basin

\begin{abstract}
A B S T R A C T
Improving surface irrigation systems for cotton in Ras-El-Ain district, Northeast Syria, needs finding alternative solutions that provide for both water saving and farm economic benefits in a context of small and family farms. Multicriteria analysis was used to evaluate and rank a set of furrow and border irrigation alternatives, with and without precise land leveling, that were created with the decision support system SADREG. This approach allowed to consider various criteria, mainly water saving and farm economics. Results show that both graded furrow and border alternatives are acceptable, with a slight advantage for graded furrows. Alternatives without land leveling have shown to be more appropriate when focusing farm economic results, while alternatives including land leveling were selected when priorities were assigned to water saving. These results relate with higher costs of alternatives that consider land leveling. Equipment for appropriate control of inflow rates was considered for all cases. The improved alternatives may lead to savings of $20-28 \%$ of irrigation water and increasing the irrigation water productivity from present 0.31 to $0.44 \mathrm{~kg} \mathrm{~m}^{-3}$. When the same alternatives were ranked for a $20 \%$ deficit irrigation their rankings changed, with reduced ranks of alternatives requiring land leveling. This is due to the fact that yields and yield values are reduced with deficit irrigation, thus making it less favorable to select alternatives that imply higher costs. The study shows that adopting more advanced but more costly irrigation technologies aimed at water saving requires appropriate economic incentives, training of farmers and an institutional framework able to support the sustainable use of water in irrigation.
\end{abstract}

(c) 2012 Elsevier B.V. All rights reserved.

\section{Introduction}

This study refers to Ras-El-Ain area, Northeast of Syria, in the Euphrates basin, an ancient fertile region where wheat and cotton are grown under surface irrigation, predominantly traditional basin and furrow irrigation. This area is heavily affected by water scarcity and the drawdown of the ground water table due to several factors related to climate aridity, increased needs for irrigation with heavy use of available water resources and, mainly, due to the enormous decrease of the Khabour river flow to only $18 \%$ of its former discharges due to the recent increase of irrigation areas both in Syria and Turkey, including groundwater irrigation in the nearby plain of Harran (Öztan and Axelrod, 2011). Unsustainable water use in this region was identified earlier (Beaumont, 1996; Hole, 2009). A necessary agreement between both countries relative to the use of the large international aquifer whose sources feed the Khabour river

\footnotetext{
* Corresponding author at: CEER - Biosystems Engineering, Institute of Agronomy, Technical University of Lisbon, Tapada de Ajuda, 1349-017 Lisboa, Portugal. Tel.: +351 213653339; fax: +351213653287.

E-mail address: lspereira@isa.utl.pt (L.S. Pereira).
}

is required to avoid its depletion; unfortunately, it is difficult to be signed in the present international context.

Cotton cropland is about $20 \%$ of the irrigated area; cotton is the main cash crop in the region and has a very strategic value (Shweih, 2006; Al Ashkar, 2009; MAAR, 2011). However, cotton is a high water demand crop (Chapagain et al., 2006) that seriously impacts the reduced water availability of Syria, particularly in Mesopotamia (Sadiddin, 2009; Sadiddin and Atiya, 2009). A sustainable irrigated agriculture requires the adoption of appropriate technologies including the modernization of traditional irrigation systems focusing water savings and economic water productivity enhancement (Oweis et al., 2011; Pereira et al., 2012).

Surface irrigation systems are used in the area, which is part of Mesopotamia, after centuries or millennia (McCorriston and Weisberg, 2002; Kamash, 2012). Commonly, farmers apply traditional irrigation methods, which are highly labor demanding and whose performance is often low, with a beneficial water use fraction (BWUF, Pereira et al., 2012) of about 0.5, and irrigation water productivity (WP irrig ) of 0.28 to $0.32 \mathrm{~kg} \mathrm{~m}^{-3}$ of cotton. However, surface irrigation has a high potential for modernization and achieving good performance including for cotton (Hunsaker et al., 1998; Pereira et al., 2002; Smith et al., 2005; Horst et al., 2007; 
Subramani and Martin, 2012). The performance of surface irrigation systems highly depends upon the design process (Gonçalves et al., 2011), which is related with the appropriateness and precision of land leveling, field shape and dimensions, and inflow discharge. In addition, the soil infiltration characteristics, that are spatially and seasonally variable, significantly influence the system performance. Field system design and operation are therefore complex. Moreover, the irrigation performance also depends on farmer irrigation decisions, mainly in relation to land leveling maintenance, timeliness and time duration of every irrigation event, and on farmer's ability to overcome difficulties in water supply, such as uncertainty or scheduling constraints (Pereira et al., 2002). However, it is necessary to search for solutions that achieve adequate compatibility among irrigation performance, water saving and economic viability for farmers, which represent conditions for sustainable irrigation. This subject is well discussed by Wichelns and Oster (2006), who realistically conclude that achieving the desirable sustainability implies direct costs and environmental impacts. The use of decision support systems (DSS) based upon multicriteria analysis (MCA) could be appropriate to find related solutions, particularly when dealing with various and contradictory criteria (Roy and Bouyssou, 1993), such as in surface irrigation design (Gonçalves and Pereira, 2009).

DSS are powerful tools for user decision aid because they integrate data and design and selection models, which allow easy creation and screening of management and design alternatives, therefore their ranking and selection following a variety of criteria. Their application in farm irrigation is useful because it allows associating hydraulics, irrigation performance, environmental and economic criteria in irrigation scheduling (Thysen and Detlefsen, 2006; Richards et al., 2008; Chen et al., 2012) and irrigation systems design (Hornbuckle et al., 2005; Pedras et al., 2009; Gonçalves and Pereira, 2009; Gonçalves et al., 2011).

The objective of this study is to analyze and evaluate the potential of modernizing surface irrigation of cotton, particularly with furrow and border irrigation methods for sustainable irrigated agriculture focusing the compatibility between water saving and economic viability. Aiming at this objective, the study applies MCA through the use of the DSS model SADREG to rank and select a set of design alternatives considering various decision criteria relative to irrigation performances, water saving and economic impacts.

\section{Materials and methods}

\subsection{The study area and field characteristics}

Ras-El-Ain district is located in Mesopotamia, in the Euphrates basin, Al Hassakeh governorate. Ras-El-Ain was known for its important karst springs (Burdon and Safadi, 1963), which have been over-exploited, causing that piezometric heads continuously fall down, some sources dried out and land subsidence has occurred. This over-exploitation is due to the need to compensate for the decrease of Khabour river flows to only $18 \%$ of former discharges after development of groundwater irrigated areas in Turkey and Syria, that produced a great decrease of flow rates of the sources that supply the river, in association with lack of international agreements and poor regional water management (Hole, 2009; Sadiddin, 2009; Öztan and Axelrod, 2011).

Climate is semi-arid, with annual rainfall ranging $160-350 \mathrm{~mm}$ and potential evaporation of $1600-2800 \mathrm{~mm}$. Air temperature often reaches $43^{\circ} \mathrm{C}$ in July and August and decreases to $4{ }^{\circ} \mathrm{C}$ in winter months. The predominant wind blows from the west and wind speed averages $2.3 \mathrm{~m} \mathrm{~s}^{-1}$ during the summer. Land elevation ranges from 165 to $325 \mathrm{~m}$ a.s.l. Further information on the area and its agriculture is provided by Galli et al. (2010).
Table 1

Parameters of the Kostiakov infiltration curves typical for Ras-El-Ain.

\begin{tabular}{llll}
\hline Infiltration curves & $k\left(\mathrm{~m}^{3} \mathrm{~m}^{-1} \mathrm{~min}^{-a}\right)$ & $a$ & $f_{0}\left(\mathrm{~m}^{3} \mathrm{~m}^{-1} \mathrm{~min}^{-1}\right)$ \\
\hline Lower infiltration & 0.0126 & 0.2110 & 0.000130 \\
Medium infiltration & 0.0118 & 0.3227 & 0.000167 \\
Higher infiltration & 0.0170 & 0.3302 & 0.000210 \\
\hline
\end{tabular}

The traditional irrigation systems are the furrowed zigzag basins and border irrigation. These systems are typical of small and family farms in the region. The furrowed zigzag basin irrigation is practiced in long stripes of land, normally with $2-5 \mathrm{~m}$ wide and 30-150 $\mathrm{m}$ long, where the available discharge is divided into several strips that are irrigated simultaneously. Despite it is quite well adapted to existing field conditions without land leveling, it is labor consuming, and imposes limitations to mechanization. The resulting distribution uniformity is low (Darouich et al., 2007; Janat, 2008).

Cotton is the main cash crop in Al-Hassakeh governorate, with a cultivated area of 56,100 ha. The present yield achieved is $4600 \mathrm{~kg} \mathrm{ha}^{-1}$. A yield increase to about $5000 \mathrm{~kg} \mathrm{ha}^{-1}$ is expected if irrigation and crop practices are improved (Janat, 2008; Oweis et al., 2011).

Field experiments were carried out in two farm sites typical of cotton croplands in the area. Soils are silt to clay textured, and the average soil water availability was $139 \mathrm{~mm} \mathrm{~m}^{-1}$. The determination of infiltration characteristics was performed through field evaluations. The modified Kostiakov infiltration equation was adopted:

$Z=k \cdot \tau^{a}+f_{0} \cdot \tau$

where $Z$ is cumulative infiltration $\left(\mathrm{m}^{3} \mathrm{~m}^{-1}\right), \tau$ is infiltration opportunity time ( $\mathrm{min}), k$ is an empirical coefficient $\left(\mathrm{m}^{3} \mathrm{~m}^{-1} \mathrm{~min}^{-a}\right), a$ is an empirical exponent (dimensionless), and $f_{0}$ is the empirical base infiltration rate $\left(\mathrm{m}^{3} \mathrm{~min}^{-1} \mathrm{~m}^{-1}\right)$. Field evaluations (Walker and Skogerboe, 1987; ASAE, 2003; Horst et al., 2005) included the double ring infiltrometer, the volumetric balance during the irrigation advance phase to get an approximation of parameters $k$ and $a$, and the furrow inflow-outflow balance after infiltration was stabilized to obtain the parameter $f_{0}$. The inverse mode simulation with SIRMOD model was used with observed advance and recession data to optimize the $k$ and $a$ parameters. The typical infiltration parameters obtained from field observations are given in Table 1 ; high infiltration rate soils are rare in the area.

\subsection{SADREG model}

SADREG is a DSS model developed to assist designers and managers in the process of designing and planning improvements in farm surface irrigation systems (Gonçalves and Pereira, 2009; Gonçalves et al., 2011). The design component applies database information and produces a set of alternatives in agreement with the user options. These alternatives are characterized by various hydraulic, economic and environmental indicators. The alternatives having main characteristics in common are grouped in projects as described by Gonçalves and Pereira (2009). The ranking and selection component is based on MCA.

The main steps on a SADREG application are:

(1) Identification of field characteristics of a rectangular shape field

(2) Data input to characterize water supply and distribution equipment.

(3) Data input referring to crop and soil data, mainly the infiltration parameters (Table 1 ).

(4) Crop irrigation scheduling, created through interactive simulations with the ISAREG model (Pereira et al., 2003). 
Table 2

Main characteristics of improved graded furrows (GF) and borders (GB).

\begin{tabular}{|c|c|c|c|c|c|c|}
\hline Project & Irrigation method & Tail end condition & Soil surface condition & Number of irrigations & Target irrigation depth (mm) & Distribution system \\
\hline GF & Graded furrow & Open & Furrowed with $0.70 \mathrm{~m}$ spacing & 10 & 80 & Gated layflat tubing \\
\hline GB & Graded border & Open & Flat soil surface & 10 & 80 & Gated layflat tubing \\
\hline
\end{tabular}

(5) Design options to create the alternatives, using the SIRMOD hydraulics simulation tool (Walker, 1998).

(6) Ranking and selection of alternatives with MCA, whose weights are defined according to the user priorities.

\subsection{Project characteristics for improvement the irrigation systems}

The projects considered refer to graded furrows (GF) and graded borders (GB), using the options presented in Table 2. Simulations were performed assuming two scenarios: (1) without land leveling operation (identified $\mathrm{GF}_{\mathrm{NLL}}$ and $\mathrm{GB}_{\mathrm{NLL}}$ ), which corresponds to reduced costs and less good irrigation performance; (2) considering precise land leveling and upgraded water use and irrigation performance. The reference situation corresponds to the traditional zigzag furrowed basins system, whose attributes correspond to average field observations.

The crop cycle duration is 170 days, with planting by May 1 st and planting density of 71,400 plants ha ${ }^{-1}$. The maximum yield achievable is $5000 \mathrm{~kg} \mathrm{ha}^{-1}$. The average net water irrigation requirements correspond to 10 irrigation events, each one with $80 \mathrm{~mm}$ depth. The total amount of irrigation is in agreement with results reported by Farahani et al. (2009) and Oweis et al. (2011) for Syria, Karam et al. (2006) for Near East, Cholpankulov et al. (2008) and Pereira et al. (2009) for Central Asia, and Chapagain et al. (2006) for other producing areas having a similar climate.

A water-yield function was used to estimate crop yields as a function of the total water use during the irrigation season following the methodology proposed by Solomon (1984) and using regional data (Yazar et al., 2002; Dağdelen et al., 2009). This function $Y_{\mathrm{a}} / Y_{\max }=f\left(W_{\mathrm{a}} / W_{\max }\right)$ relates the relative yield with the relative net water availability and refers to both deficit and excess irrigation. $Y_{\mathrm{a}}$ and $Y_{\max }$ are the actual and the maximum yield, that are achieved when the net applied water are, respectively, $W_{\mathrm{a}}$ and $W_{\max }($ Table 3 ).

The reference field used to represent the majority of fields in Ras-El-Ain area is $100 \mathrm{~m}$ long and $50 \mathrm{~m}$ wide, with $0.8 \%$ longitudinal slope, zero cross slope and medium infiltration characteristics (Table 1). The available discharge is $401 \mathrm{~s}^{-1}$. Hydraulics simulations were performed assuming a Manning roughness coefficient of $0.04 \mathrm{~m}^{1 / 3} \mathrm{~s}^{-1}$ for furrows, and $0.16 \mathrm{~m}^{1 / 3} \mathrm{~s}^{-1}$ for graded borders. For this typical field, full and deficit irrigation were considered, with net irrigation of 800 and $640 \mathrm{~mm}$, respectively. The economic and labor input data applied are presented in Table 4.

\subsection{Multicriteria analysis}

The characterization of the design alternatives was performed with the performance indicators defined by Gonçalves and Pereira (2009) and Gonçalves et al. (2011), listed in Table 5. In this study, two other indicators defined by Pereira et al. (2012) were added:

Table 3

Empirical water-yield function.

\begin{tabular}{llllllll}
\hline$W_{\mathrm{a}} / W_{\max }$ & 0.25 & 0.5 & 0.75 & 1.0 & 1.5 & 2.0 & 2.5 \\
$Y_{\mathrm{a}} / Y_{\max }$ & 0.10 & 0.56 & 0.85 & 1.0 & 0.97 & 0.9 & 0.73 \\
\hline
\end{tabular}

Note: $Y_{\mathrm{a}}$ and $Y_{\max }$ are the actual and the maximum yields, that correspond to the net applied water $W_{\mathrm{a}}$ and $W_{\max }$ respectively.
(1) the beneficial water use fraction (BWUF), relating the beneficial fraction of applied irrigation water to the total irrigation water, and (2) the economic water productivity ratio (EWPR), that relates the yield value with the total costs for mobilizing and applying water to achieve that yield.

The adopted criteria to be considered in ranking with MCA refer to the attributes and utility functions described in Table 5, which enable comparing variables having different units. The utilities $U_{j}$ relative to any criterion $j$ were normalized into the [0-1] interval, with zero for the more adverse and 1 for the most advantageous result. Linear utility functions were applied:

$U_{j}\left(x_{j}\right)=\alpha \cdot x_{j}+\beta_{j}$

where $x_{j}$ is attribute $j, \alpha$ is graph slope and $\beta$ is the utility value $U_{j}\left(x_{j}\right)$ for a null attribute. The slope, $\alpha$, is negative for criteria like costs and water use, whose highest values are the worse, and positive for other criteria like benefits ELP, EWP and $\mathrm{WP}_{\text {Irrig, }}$, whose higher values are the best. The utility parameters were determined according to the full set of alternatives including the reference present condition.

The decision maker priorities are modeled by the criterion weights $\left(\lambda_{j}\right)$, which represent the relative importance of each criterion $j$ as viewed by the decision maker. Criterion weights depend upon several factors, including socio-cultural, economic and environmental ones. Weights applied to the various attributes are listed in Table 5 in relation to water saving and environmental criteria (water saving), and to economic results at farm level (farm economics).

The MCA method applied is the linear weighted summation (Pomerol and Romero, 2000), a full compensatory and aggregative method, which has the major advantage of its high simplicity, allowing an easier understanding of the procedure and results. However, this method has the disadvantage of full compensatory assumption, i.e., any criterion with lower results can be compensated by another one with better results, which is a trade-off

Table 4

Economical and labor data.

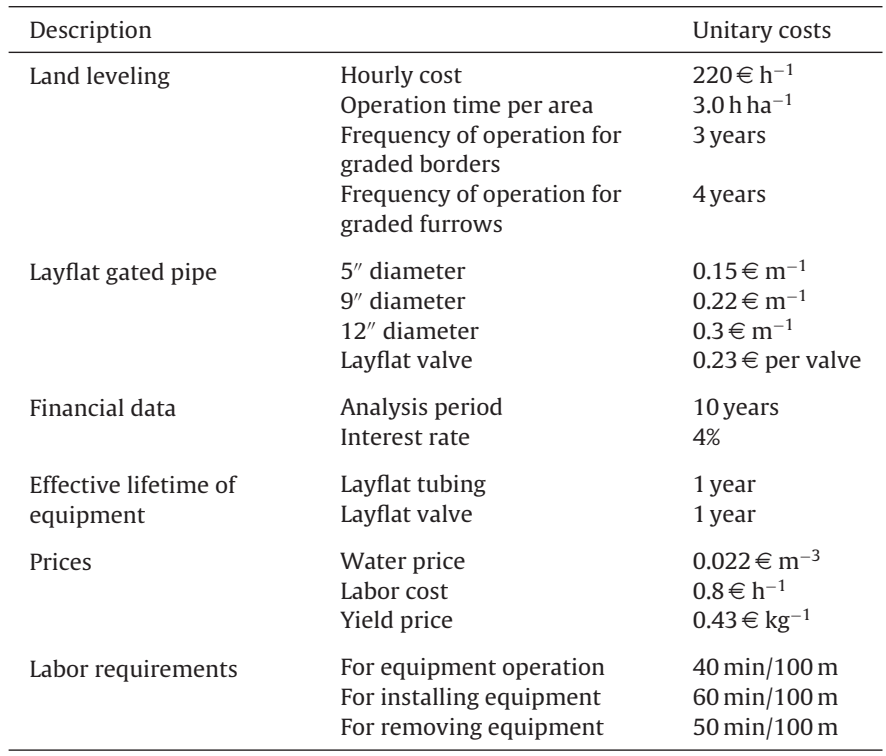


Table 5

Criteria attributes, utility functions and criteria weights.

\begin{tabular}{|c|c|c|c|c|c|}
\hline \multirow[t]{2}{*}{ Criteria attributes $(x)$} & \multirow[t]{2}{*}{ Symbol } & \multirow[t]{2}{*}{ Units } & \multirow[t]{2}{*}{ Utility functions } & \multicolumn{2}{|c|}{$\begin{array}{l}\text { Weights (\%) assigned to attributes } \\
\text { when considering }\end{array}$} \\
\hline & & & & Water saving & Farm economics \\
\hline \multicolumn{6}{|l|}{ Economic productivity and costs } \\
\hline Economic land productivity & ELP & $€ \mathrm{ha}^{-1}$ & $U(x)=0.280 \times 10^{-3} x$ & 2.5 & 15 \\
\hline Economic water productivity & EWP & $€ \mathrm{~m}^{-3}$ & $U(x)=4.3 x$ & 2.5 & 10 \\
\hline Economic water productivity ratio & EWPR & Ratio & $U(x)=0.25 x$ & 5 & 20 \\
\hline Fixed irrigation costs & FIC & $€ \mathrm{ha}^{-1}$ & $U(x)=1-0.001 x$ & 5 & 20 \\
\hline Variable irrigation costs & VIC & $€ \mathrm{ha}^{-1}$ & $U(x)=1-0.001 x$ & 5 & 15 \\
\hline \multicolumn{6}{|l|}{ Water saving and environment } \\
\hline Total irrigation water use & IWU & $\mathrm{m}^{3} \mathrm{ha}^{-1}$ & $U(x)=2.22-0.106 \times 10^{-3} x$ & 15 & 5 \\
\hline Beneficial water use fraction & BWUF & Ratio & $U(\mathrm{x})=1.429 x$ & 20 & 5 \\
\hline Irrigation water productivity & $\mathrm{WP}_{\text {Irrig }}$ & $\mathrm{kg} \mathrm{m}^{-3}$ & $U(x)=2.22 x$ & 15 & 5 \\
\hline Irrigation tail-end runoff & RO & $\mathrm{m}^{3} \mathrm{ha}^{-1}$ & $U(x)=1-0.100 \times 10^{-3} x$ & 15 & 2.5 \\
\hline Irrigation deep percolation & DP & $\mathrm{m}^{3} \mathrm{ha}^{-1}$ & $U(x)=1-0.100 \times 10^{-3} x$ & 15 & 2.5 \\
\hline
\end{tabular}

that may not be well accepted by the decision makers. For each alternative, the method allows the calculation of a global utility that represents its integrative score performance:

$U=\sum_{j=1}^{N c} \lambda_{j} U_{j}$

where $U$ is the global utility, scaled in the [0-1] interval, Nc is the number of criteria, $\lambda_{j}$ is the weight assigned to criterion $j$, and $U_{j}$ is the utility relative to criterion $j$ (Table 5 ).

In this study, differently from a common design study, weights relative to farm economics and water saving criteria were progressively varied from a scenario where $90 \%$ of weights were assigned to farm economic criteria to a last scenario where $90 \%$ of weights were assigned to water saving. Analyzing the rankings corresponding to these 9 weighing scenarios, W1 to W9, it could be possible to assess how alternatives respond to farm economics and water saving criteria.

\section{Results and discussion}

\subsection{Water use performance, water saving, and farm economics}

SADREG simulations created a set of 62 alternatives for the reference field, including scenarios with and without improved land leveling. This set was screened by removing the non-satisfactory ones, where the total irrigation water use (IWU) was larger than the average value observed in field, $16,200 \mathrm{~m}^{3} \mathrm{ha}^{-1}$. The characteristics of traditional irrigation method of furrowed zigzag basin were obtained from field observations in Ras-El-Ain area.

Results for IWU, irrigation tail-end runoff (RO) and deep percolation (DP) are presented in Fig. 1a for the traditional and the satisfactory alternatives relative to both project types, GF and GB. Results show that the improved alternatives retained allow a significant decrease of IWU due to reduced deep percolation and runoff. Lower IWU correspond to GF(0.4) and GB(1.1) - numbers inside brackets refer to the unit inflow rate, $1 \mathrm{~s}^{-1}$ per furrow or $1 \mathrm{~s}^{-1}$ per $\mathrm{m}$ width of a border - but non-lasered leveling solutions $\mathrm{GF}_{\mathrm{NLL}}(0.4)$ and $\mathrm{GB}_{\mathrm{NLL}}(1.1)$ show not very different results relative to the lasered ones because reducing RO and DP mainly depends on the ability to control unit inflow rates applied. In other words, IWU and RO are very sensitive to the unit inflow rate, thus indicating that an improved performance requires appropriate control of inflow rates by farmers, i.e., that adequate equipment, such as gated layflat tubing, is available for that purpose. Replacing the traditional zigzag furrowed basins by graded furrows or borders increases the risk of producing high tail-end runoff if farmers do not have appropriate equipment and conditions to achieve a good control of the inflow discharges and cutoff time. This implies both investment and know-how. Meanwhile, results for RO (Fig. 1) show that a potential exists for runoff reuse in irrigation, although these techniques increase the fixed and operative irrigation costs, as well as the operational complexity of the systems.

As expected, the beneficial water use fraction varies contrarily to IWU since its increase represents the ability to control RO and $\mathrm{DP}$ (Fig. 1a and b). The best alternatives, GF(0.4) and GB(1.1), led to IWU of 1150 and $1170 \mathrm{~mm}$, respectively, which represent a reduction of $21-28 \%$ relative to the observed values, $1450-1620 \mathrm{~mm}$. This reduction corresponds to an increase of the BWUF from observed $0.49-0.55$ to 0.69 and 0.68 , respectively, for $\mathrm{GF}(0.4)$ and $\mathrm{GB}(1.1)$ although $\mathrm{GF}_{\mathrm{NLL}}(0.4)$ produced $\mathrm{BWUF}=0.65$ and $\mathrm{GB}_{\mathrm{NLL}}(1.1)$ led to $\mathrm{BWUF}=0.62$. This result for $\mathrm{GF}_{\mathrm{NLL}}(0.4)$ a non-lasered field is in agreement with the adoption of graded furrows with small discharges by best farmers in the region. Results in Fig. 1(c) for $\mathrm{WP}_{\text {Irrig }}$ vary in agreement with BWUF because crop yields change little among alternatives. The best performing alternatives, GF(0.4) and $\mathrm{GB}(1.1)$, had $\mathrm{WP}_{\text {Irrig }}$ of 0.44 and $0.43 \mathrm{~kg} \mathrm{~m}^{-3}$, respectively, much above that of the reference, $0.31 \mathrm{~kg} \mathrm{~m}^{-3}$, and similar to those predicted by Oweis et al. (2011). However, $\mathrm{GF}_{\mathrm{NLL}}(0.4)$ and $\mathrm{GB}_{\mathrm{NLL}}(1.1)$ produced $W_{\text {Irrig }}$ of 0.40 and $0.39 \mathrm{~kg} \mathrm{~m}^{-3}$, respectively, thus representing a reasonable improvement relative to present and not requiring investment in precision laser leveling.

Results from comparing costs are presented in Fig. 2a. It shows that the improved solutions require a higher cost than the traditional one, with a difference of $200-280 € \mathrm{ha}^{-1}$ or $40-100 € \mathrm{ha}^{-1}$ is for the solutions with or without land leveling, respectively. The fixed costs represented a small fraction of the total costs and concern the investments for the acquisition of the gated layflat tubing distribution system. Because land leveling requires periodic maintenance, related costs were all included in the variable costs. The operation costs vary among alternatives because they refer to land leveling, and, mainly, to water and labor costs, which depend upon the amount of water use; thus, operation costs are higher for the alternatives using larger inflow rates that lead to higher tail-end runoff. Differences between $\mathrm{GF}_{\mathrm{NLL}}$ and $\mathrm{GB}_{\mathrm{NLL}}$ were small (Fig. 2a). EWPR is highest for the traditional system (Fig. 2b). This indicates that the currently adopted system is the one that better relates the achieved yield value with the irrigation and water costs. EWPR is higher for the alternatives with lower costs, when laser leveling is not considered and is lower when irrigation costs increase with land leveling. This means that farmers need some incentives or compensation if they should select alternatives requiring higher costs in order to achieve water saving. Results indicate that the economic value of the water saved due to land leveling does not compensate for the related costs. In addition, results show that equipment that may control discharges and cutoff time play a major role in water saving when compared to land leveling. 

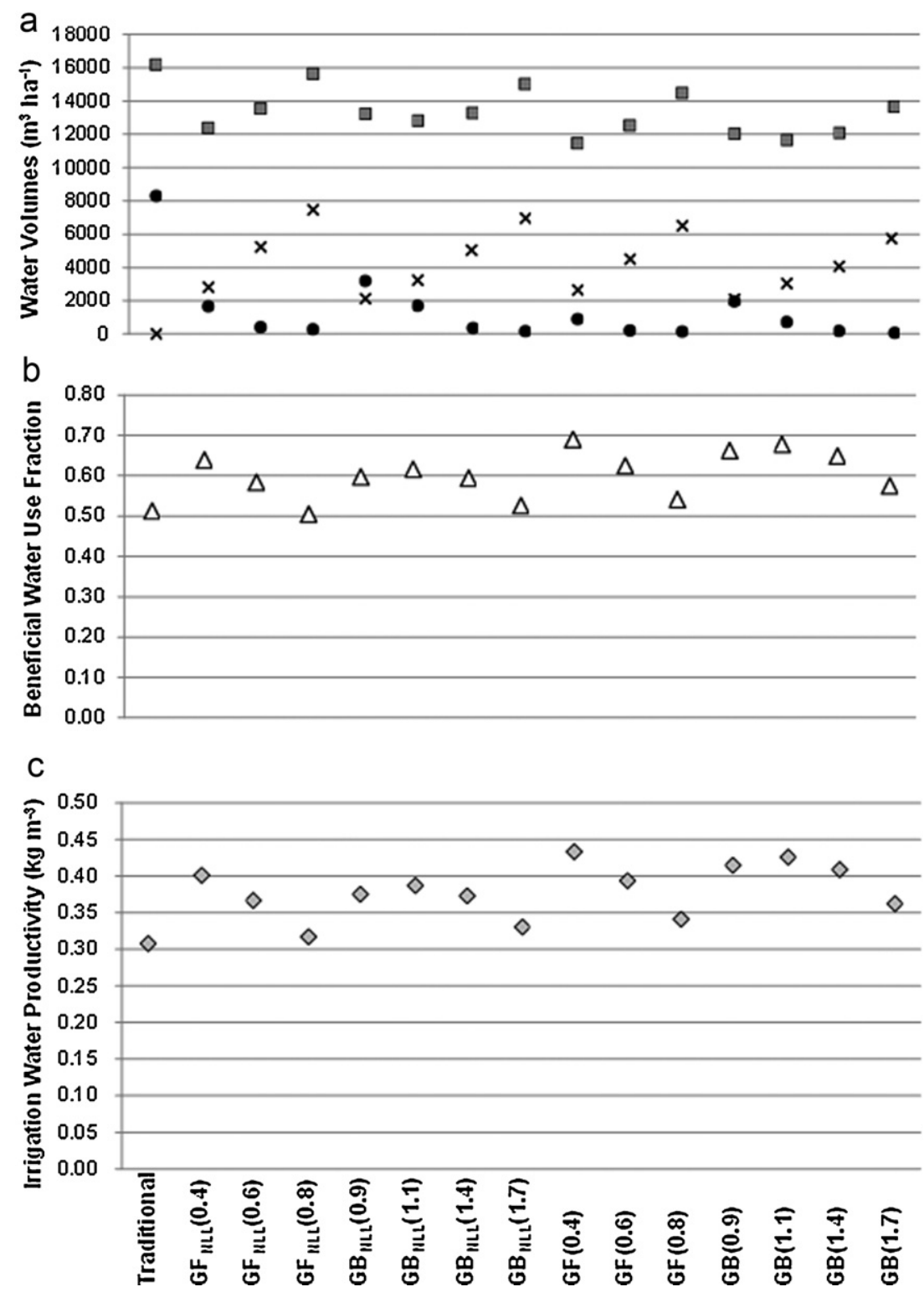

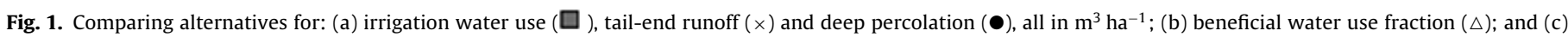

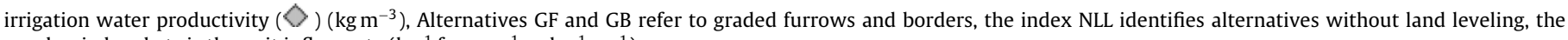
number in brackets is the unit inflow rate $\left(1 \mathrm{~s}^{-1}\right.$ furrow ${ }^{-1}$ or $\left.1 \mathrm{~s}^{-1} \mathrm{~m}^{-1}\right)$.

\subsection{Water saving $v$ s. farm economic issues}

Fig. 3 presents the global utilities $(U)$ characterizing the traditional and the satisfactory alternatives for the priority scenarios defined through the criteria weights in Table 5. Results show that $U$ values for the economics priority are larger than those for water saving only for the traditional reference case and for some non-lasered GF and GB. The reference traditional system has the lowest utility value associated with water saving. Contrarily, the alternatives relative with adoption of laser leveling, have higher $U$ values associated with water saving. Results also show that there are no disagreements on ranking among the best alternatives for GF and GB with or without land leveling. This could be expected considering the results relative to water use (Fig. 1) and costs (Fig. 2).

To analyze the compatibility between water saving and economic issues the alternatives were ranked following various weighing approaches, W1 to W9. W1 is a weighing scenario where
$90 \%$ of the weights are assigned to the economic criteria and $10 \%$ to the water saving criteria (Table 5), W2 corresponds to changing weights to, respectively, 80 and 20\%, then W3 through W9 are scenarios where weights progressively inter-changed with W9 having $10 \%$ of weights assigned to economic criteria and $90 \%$ assigned to water saving criteria. It results that the sum of $U(x)$ values relative to farm economic criteria decreases from W1 to W9 contrarily to the sum of $U(x)$ relative to water saving (Fig. 4 ).

The ranking of alternative solutions for the scenarios W1 to W9 are shown in Table 6 with identification of the solutions that ranked 1-5. For W1, a scenario where high weights are assigned to economic issues and low ones to water saving, the first four ranked alternatives refer to GF and GB without laser leveling, with $\mathrm{GF}_{\mathrm{NLL}}(0.4)$ ranking first, and the fifth is the traditional system. The latter disappear for W2 and GF(0.4), a land leveling alternative, is ranked third. $\mathrm{GF}_{\mathrm{NLL}}(0.4)$ ranks first also for scenarios W2 and W3, and keeps being an option until the scenario W9, where very high priority is assigned to water saving. The alternative $G_{\mathrm{NLL}}(1.1)$ is 

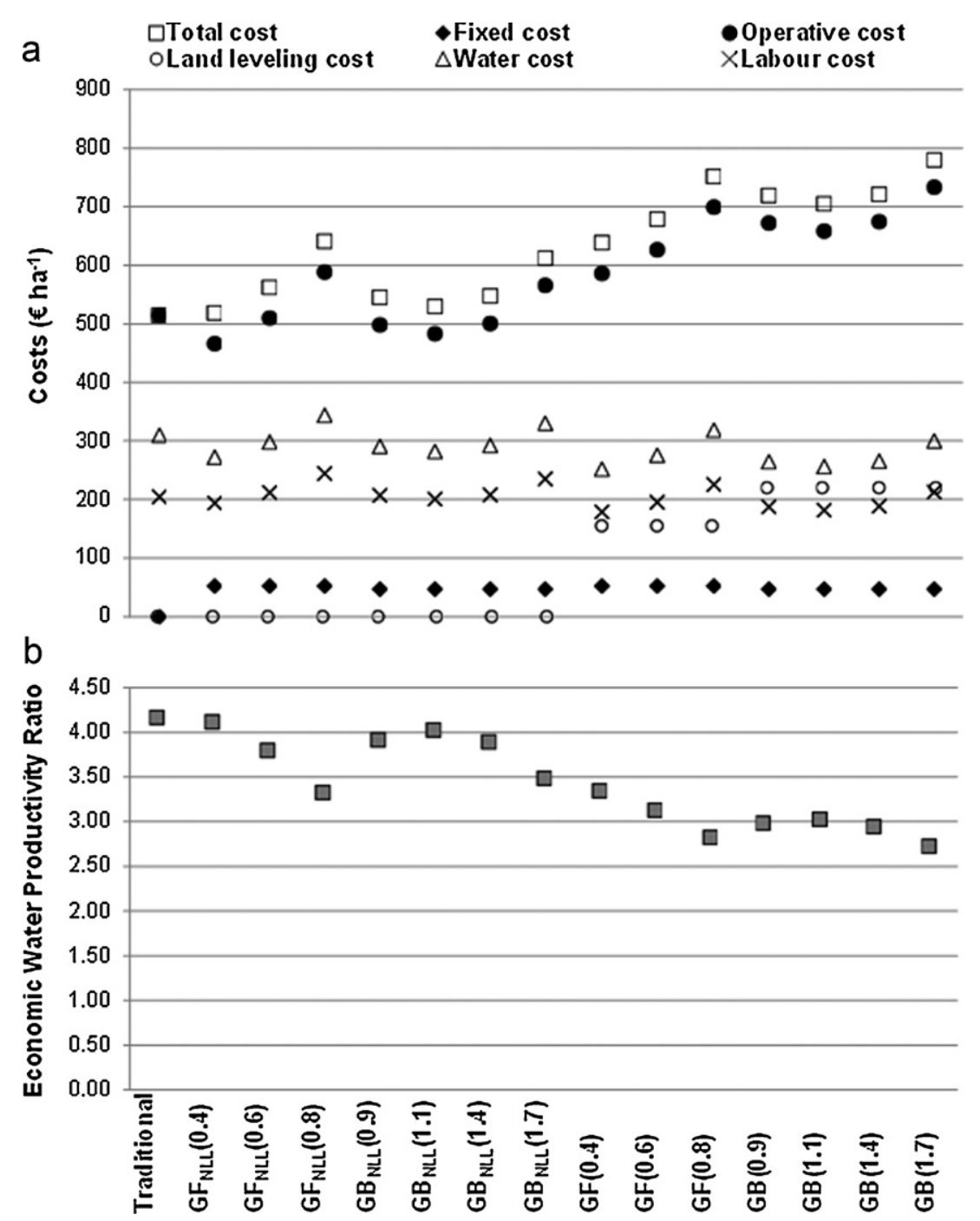

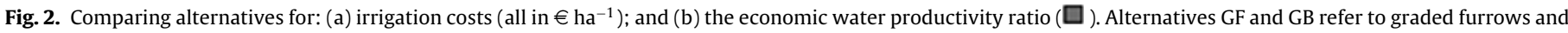
borders, the index NLL identifies alternatives without land leveling, the number in brackets is the unit inflow rate $\left(1 \mathrm{~s}^{-1}\right.$ furrow $\mathrm{w}^{-1}$ or $\left.1 \mathrm{~s}^{-1} \mathrm{~m}^{-1}\right)$.

second ranked for $\mathrm{W} 1$ and $\mathrm{W} 2$, and is kept among the first five until scenario W6. The first ranked for W4 is GF(0.4), that remains first ranked for all successive scenarios, while $\mathrm{GB}(1.1)$ is generally second ranked after scenario W5. For scenario W9, three GB

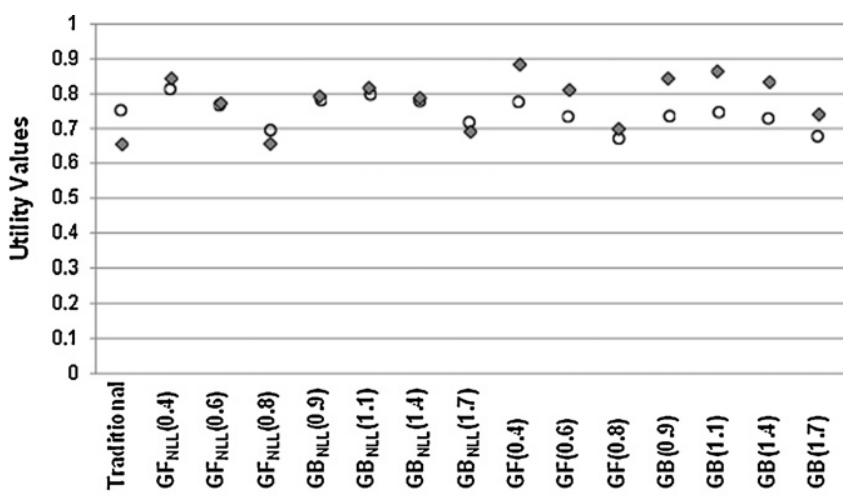

Fig. 3. Global utility values when the priority is assigned to economic issues $(\bigcirc)$ or to water saving $(\diamond)$. Alternatives GF and GB refer to graded furrows and borders, the index NLL identifies alternatives without land leveling, and the number in brackets is the unit inflow rate $\left(1 \mathrm{~s}^{-1}\right.$ furrow ${ }^{-1}$ or $\left.1 \mathrm{~s}^{-1} \mathrm{~m}^{-1}\right)$. alternatives are ranked among the first five. These ranking results indicate that for fields $100 \mathrm{~m}$ long, $0.8 \%$ slope and medium infiltration characteristics the best solutions are graded furrows with or without land leveling when it is possible to control the inflow rate at $0.41 \mathrm{~s}^{-1}$ per furrow, as already tested in farmers fields using locally developed equipment (Galli et al., 2010). Graded borders look to be good options when land leveling is adopted and results show that these alternatives are less dependent upon inflow rates than GF. The fact that the traditional zigzag furrowed basins rank fifth for scenario 1 indicates that the farmers option for this system is adequate when farmers have not the economic and technological means to adopt upgraded systems and equipment.

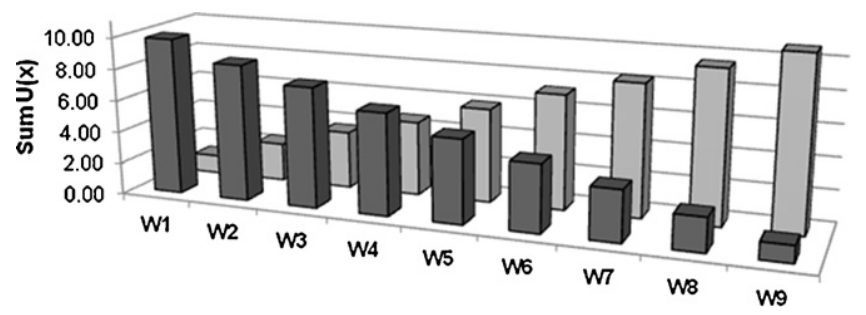

Fig. 4. Changes in the sum of utility values $U(x)$ associated with economic $(\square)$ and water saving $(\square)$ criteria for the weighting scenarios W1 to W9. 
Table 6

Ranking of the alternative solutions for the various weighing scenarios W1 (highest weights to economic issues) through W9 (highest weights to water saving).

\begin{tabular}{|c|c|c|c|c|c|c|c|c|c|}
\hline \multirow[t]{2}{*}{ Rank } & \multicolumn{9}{|c|}{ Weighing scenarios, with progressively decreasing weights to economic issues and increasing weights to water saving } \\
\hline & W1 (90-10) & W2 (80-20) & W3 (70-30) & W4 (60-40) & W5 (50-50) & W6 $(40-60)$ & W7 (30-70) & W8 (20-80) & W9 (10-90) \\
\hline 1 & $\mathrm{GF}_{\mathrm{NLL}}(0.4)$ & $\mathrm{GF}_{\mathrm{NLL}}(0.4)$ & $\mathrm{GF}_{\mathrm{NLL}}(0.4)$ & $\mathrm{GF}(0.4)$ & $\mathrm{GF}(0.4)$ & $\mathrm{GF}(0.4)$ & $\mathrm{GF}(0.4)$ & $\mathrm{GF}(0.4)$ & $\mathrm{GF}(0.4)$ \\
\hline 2 & $\mathrm{~GB}_{\mathrm{NLL}}(1.1)$ & $\mathrm{GB}_{\mathrm{NLL}}(1.1)$ & $\mathrm{GF}(0.4)$ & $\mathrm{GF}_{\mathrm{NLL}}(0.4)$ & $\mathrm{GB}(1.1)$ & $\mathrm{GF}_{\mathrm{NLL}}(0.4)$ & $\mathrm{GB}(1.1)$ & $\mathrm{GB}(1.1)$ & $\mathrm{GB}(1.1)$ \\
\hline 3 & $\mathrm{~GB}_{\mathrm{NLL}}(0.9)$ & GF(0.4) & $\mathrm{GB}_{\mathrm{NLL}}(1.1)$ & $\mathrm{GB}_{\mathrm{NLL}}(1.1)$ & $\mathrm{GF}_{\mathrm{NLL}}(0.4)$ & $\mathrm{GB}(1.1)$ & $\mathrm{GF}_{\mathrm{NLL}}(0.4)$ & $\mathrm{GB}(0.9)$ & $\mathrm{GB}(0.9)$ \\
\hline 4 & $\mathrm{~GB}_{\mathrm{NLL}}(1.4)$ & $\mathrm{GB}_{\mathrm{NLL}}(0.9)$ & $\mathrm{GB}(1.1)$ & GB(1.1) & $\mathrm{GB}(0.9)$ & $\mathrm{GB}_{\mathrm{NLL}}(1.1)$ & $\mathrm{GB}(0.9)$ & $\mathrm{GF}_{\mathrm{NLL}}(0.4)$ & $\mathrm{GB}(1.4)$ \\
\hline 5 & Traditional & $\mathrm{GB}_{\mathrm{NLL}}(1.4)$ & $\mathrm{GB}_{\mathrm{NLL}}(0.9)$ & $\mathrm{GB}_{\mathrm{NLL}}(0.9)$ & $\mathrm{GB}_{\mathrm{NLL}}(1.1)$ & $\mathrm{GB}(1.4)$ & $\mathrm{GB}(1.4)$ & GB(1.4) & $\mathrm{GF}_{\mathrm{NLL}}(0.4)$ \\
\hline
\end{tabular}

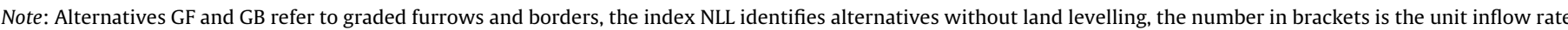
$\left(1 \mathrm{~s}^{-1}\right.$ furrow ${ }^{-1}$ or $\left.1 \mathrm{~s}^{-1} \mathrm{~m}^{-1}\right)$. The shaded values refer to non-laser leveled alternatives.

Table 7

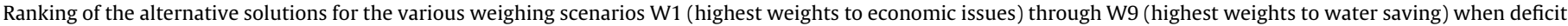
irrigation is adopted.

\begin{tabular}{|c|c|c|c|c|c|c|c|c|c|}
\hline \multirow[t]{2}{*}{ Rank } & \multicolumn{9}{|c|}{ Weighing scenarios, with progressively decreasing weights to economic issues and increasing weights to water saving } \\
\hline & W1 (90-10) & W2 (80-20) & W3 (70-30) & W4 (60-40) & W5 (50-50) & W6 (40-60) & W7 (30-70) & W8 (20-80) & W9 (10-90) \\
\hline 1 & $\mathrm{GF}_{\mathrm{NLL}}(0.4)$ & $\mathrm{GF}_{\mathrm{NLL}}(0.4)$ & $\mathrm{GF}_{\mathrm{NLL}}(0.4)$ & $\mathrm{GF}_{\mathrm{NLL}}(0.4)$ & $\mathrm{GF}_{\mathrm{NLL}}(0.4)$ & $\mathrm{GF}(0.4)$ & $\mathrm{GF}(0.4)$ & $\mathrm{GF}(0.4)$ & $\mathrm{GF}(0.4)$ \\
\hline 2 & $\mathrm{~GB}_{\mathrm{NLL}}(1.1)$ & $\mathrm{GB}_{\mathrm{NLL}}(1.1)$ & $\mathrm{GB}_{\mathrm{NLL}}(1.1)$ & $\mathrm{GB}_{\mathrm{NLL}}(1.1)$ & GF(0.4) & $\mathrm{GF}_{\mathrm{NLL}}(0.4)$ & $\mathrm{GF}_{\mathrm{NLL}}(0.4)$ & GB(1.1) & $\mathrm{GB}(1.1)$ \\
\hline 3 & $\mathrm{~GB}_{\mathrm{NLL}}(0.9)$ & $\mathrm{GB}_{\mathrm{NLL}}(0.9)$ & $\mathrm{GB}_{\mathrm{NLL}}(0.9)$ & $\mathrm{GF}(0.4)$ & $\mathrm{GB}_{\mathrm{NLL}}(1.1)$ & $\mathrm{GB}_{\mathrm{NLL}}(1.1)$ & GB(1.1) & $\mathrm{GF}_{\mathrm{NLL}}(0.4)$ & $\mathrm{GB}(0.9)$ \\
\hline 4 & $\mathrm{~GB}_{\mathrm{NLL}}(1.4)$ & $\mathrm{GB}_{\mathrm{NLL}}(1.4)$ & GF(0.4) & $\mathrm{GB}_{\mathrm{NLL}}(0.9)$ & $\mathrm{GB}(1.1)$ & GB(1.1) & $\mathrm{GB}_{\mathrm{NLL}}(1.1)$ & $\mathrm{GB}(0.9)$ & $\mathrm{GB}(1.4)$ \\
\hline 5 & $\operatorname{GF}_{\mathrm{NLL}}(0.6)$ & $\mathrm{GF}_{\mathrm{NLL}}(0.6)$ & $\mathrm{GB}_{\mathrm{NLL}}(1.4)$ & $\mathrm{GB}_{\mathrm{NLL}}(1.4)$ & $\mathrm{GB}_{\mathrm{NLL}}(0.9)$ & $\mathrm{GB}_{\mathrm{NLL}}(1.4)$ & $\mathrm{GB}(0.9)$ & $\mathrm{GB}(1.4)$ & $\operatorname{GF}_{\mathrm{NLL}}(0.4)$ \\
\hline
\end{tabular}

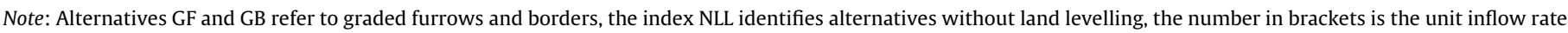
$\left(1 \mathrm{~s}^{-1}\right.$ furrow $^{-1}$ or $\left.\mathrm{l} \mathrm{s}^{-1} \mathrm{~m}^{-1}\right)$. The shaded values refer to non-laser leveled alternatives

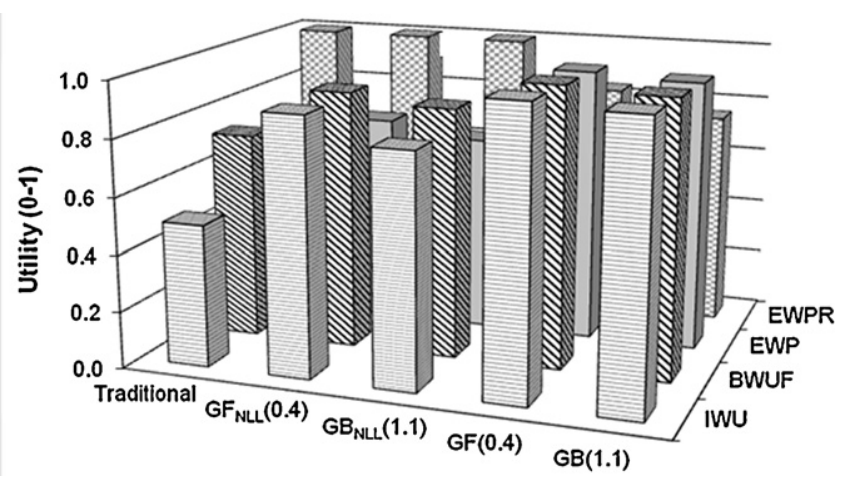

Fig. 5. Comparing the utilities of the best ranked alternatives and the traditional one for the IWU (目), BWUF ( $)$, EWP ( $\square$ ) and EWPR ( 8 ).

The alternative $\mathrm{GF}_{\mathrm{NLL}}(0.4)$ ranked first for the scenarios $\mathrm{W} 1$ to W3 (Table 6 ) because it shows a very high utility $U(x)$ relative to EWPR and the highest $U(x)$ among the non-laser leveled alternatives relative to water saving indicators BWUF, IWU and EWP(Fig. 5), i.e., showing to be the best when farm economic issues are the priority and performing reasonably well in terms of water saving. $\mathrm{GB}_{\mathrm{NLL}}(1.1)$, that ranked second for the scenarios $\mathrm{W} 1$ and $\mathrm{W} 2$, has also a very high utility relative to EWPR but smaller ones for the other indicators which relate to water saving. Fig. 5 shows that both $\mathrm{GF}(0.4)$ and $\mathrm{GB}(1.1)$, mainly the first one, have much better utilities relative to water saving, i.e., IWU, BWUF and EWP, which overall compensate for the lower utilities values relative to EWPR. Results in Fig. 5 explain well why these 2 alternatives rank better than the ones without land leveling.

\subsection{Deficit irrigation}

The ranking of alternatives when deficit irrigation is adopted, $640 \mathrm{~mm}$ instead of $800 \mathrm{~mm}$, are shown in Table 7. Rankings changed relative to those for full irrigation given in Table 6 . Because yields and yield values are reduced with deficit irrigation, the scenarios W1 to W6 have more alternatives requiring less irrigation costs ranked among the top five than alternatives requiring land leveling, The first rank for scenarios $\mathrm{W} 1$ to $\mathrm{W} 5$ is for $\mathrm{GF}_{\mathrm{NLL}}(0.4)$, and for W6 to W9 is for $\mathrm{GF}(0.4)$, i.e., furrow irrigation with controlled inflow rates without and with land leveling is selected as the best. That ranking above $\mathrm{GB}_{\mathrm{NLL}}(1.1)$ and, for land leveling alternatives, above $\mathrm{GB}(1.1)$ results from the fact that graded furrows with a small inflow rate are able to produce less non-beneficial water use and thus have better EWP and EWPR than graded borders as shown in Fig. 5. It can be concluded that alternatives more able to produce water saving are not the best ranked for deficit irrigation

Table 8

Comparing indicators relative to main alternatives for full and deficit irrigation.

\begin{tabular}{|c|c|c|c|c|c|c|}
\hline & $\operatorname{IWU}\left(\mathrm{m}^{3} \mathrm{ha}^{-1}\right)$ & BWUF (ratio) & $\mathrm{ELP}\left(€ \mathrm{ha}^{-1}\right)$ & $\mathrm{WPi}_{\text {rrig }}\left(\mathrm{kg} \mathrm{m}^{-3}\right)$ & $\mathrm{EWP}\left(€ \mathrm{~m}^{-3}\right)$ & EWPR (ratio) \\
\hline \multicolumn{7}{|l|}{ Full irrigation } \\
\hline $\operatorname{GF}_{N L L}(0.4)$ & 12384.79 & 0.64 & 2135.48 & 0.401 & 0.172 & 4.12 \\
\hline $\mathrm{GB}_{\mathrm{NLL}}(1.1)$ & 12822.26 & 0.62 & 2133.73 & 0.387 & 0.166 & 4.02 \\
\hline $\mathrm{GF}(0.4)$ & 11467.40 & 0.69 & 2135.89 & 0.433 & 0.225 & 3.34 \\
\hline $\mathrm{GB}(1.1)$ & 11656.60 & 0.68 & 2134.66 & 0.426 & 0.221 & 3.03 \\
\hline \multicolumn{7}{|c|}{ Deficit irrigation } \\
\hline $\mathrm{GF}_{\mathrm{NLL}}(0.4)$ & 9907.82 & 0.64 & 1880.39 & 0.441 & 0.190 & 4.42 \\
\hline $\mathrm{GB}_{\mathrm{NLL}}(1.1)$ & 10257.78 & 0.62 & 1878.98 & 0.426 & 0.183 & 4.33 \\
\hline $\mathrm{GF}(0.4)$ & 9173.91 & 0.69 & 1880.71 & 0.477 & 0.205 & 3.40 \\
\hline $\mathrm{GB}(1.1)$ & 9325.25 & 0.68 & 1879.72 & 0.469 & 0.202 & 3.04 \\
\hline
\end{tabular}

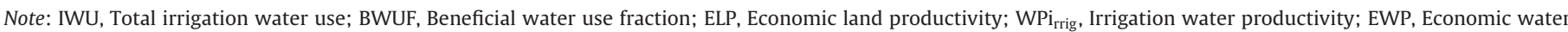

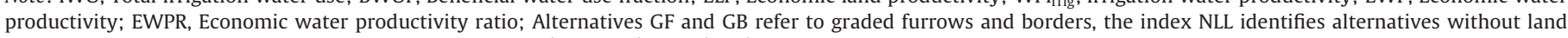
levelling, the number in brackets is the unit inflow rate $\left(1 \mathrm{~s}^{-1}\right.$ furrow ${ }^{-1}$ or $\left.1 \mathrm{~s}^{-1} \mathrm{~m}^{-1}\right)$. 
contrarily to the alternatives that better respond to farm economics criteria.

To understand these results, selected indicators relative to main alternatives are compared in Table 8 for both full and deficit irrigation. It may be observed that decreasing $20 \%$ of irrigation water use causes a decrease of ELP of only $12 \%$ because cotton responds well to a sustained deficit irrigation (Fereres and Soriano, 2007; Pereira et al., 2009). Because the decrease in water use is larger than that for yield, both $\mathrm{WP}_{\text {irrig }}$ and EWP increase about $10 \%$; however, for the land leveling alternatives, EWP increases less. Due to higher irrigation costs, EWPR increases only $1.5 \%$ for the alternatives requiring land leveling while for those not adopting it the increase is around 7\%. These results explain why alternatives designed for water saving but more costly respond less well to deficit irrigation. Nevertheless, these results do not allow concluding when deficit irrigation is feasible or not because full production costs were not considered, hence it was not possible to assess when yield values are sufficient to cover the production costs. Anyway, adopting innovation requires appropriate financial incentives and capacity building, as well as an innovative institutional framework that provides the means for farmers to adopt water saving practices.

\section{Conclusions}

Using multicriteria analysis allowed to assess the changes in ranking of various alternatives for improvement of irrigation systems when priorities were assigned to farm economics or to water saving criteria. Both full and deficit irrigation were considered. The application refers to various sets of graded furrow and border irrigation alternatives, with and without precise land leveling, that were created and analyzed with the decision support system SADREG.

Results show that both graded furrow and border alternatives are acceptable, with a slight advantage for graded furrows. Alternatives without land leveling are likely more appropriate when farm economic results are aimed, while alternatives including land leveling were highly ranked when priorities were assigned to water saving. This is due to higher costs of alternatives that consider land leveling. However, equipment for appropriate control of inflow rates was considered for all alternatives since performance highly depends upon the appropriateness of discharges and cutoff time control. The improved alternatives may lead to save up to $28 \%$ of irrigation water and to increase the irrigation water productivity from present 0.31 to $0.44 \mathrm{~kg} \mathrm{~m}^{-3}$.

Ranks changed when the same alternatives were considered for a sustained deficit irrigation of $20 \%$. Because yields and yield values are reduced with deficit irrigation it becomes less favorable to select the advanced alternatives since they are more costly. Hence, rankings changed and alternatives with land leveling could only be selected when very high priorities were assigned to water saving. Less costly alternatives were selected when farm economics was prioritized.

Results made evident that farm economics and water saving criteria are contradictory since the value of water saved when more advanced systems are used does not provide for recovering the additional costs relative to these alternatives. This study, in a context of small and family farms, shows that adopting more advanced but more costly irrigation technologies aimed at water saving requires appropriate economic incentives, training of farmers and an institutional framework able to support the sustainable use of water in irrigation.

\section{Acknowledgments}

This study is part of the project PTDC/AGR-AAM/105432/2008 funded by the Foundation for Science and Technology (FCT),
Portugal. Field work was funded by CIHEAM/IAM, Bari, Italy, and the Italian Cooperation. The first author thanks FCT for the fellowship SFRH/BD/60516/2009.

\section{References}

Al Ashkar, H.A.K., 2009. The evolution of cotton policies in Syria. International Journal of Life Sciences Special Nr. 1, 123-131.

ASAE, 2003. Evaluation of irrigation furrows. EP419.1. In: ASAE Standards. ASAE, St. Joseph, MI, pp. 919-924.

Beaumont, P., 1996. Agricultural and environmental changes in the upper Euphrates catchment of Turkey and Syria and their political and economic implications. Applied Geography 16 (2), 137-157.

Burdon, D.J., Safadi, C., 1963. Ras-el-Ain: the great karst spring of Mesopotamia, an hydrogeological study. Journal of Hydrology 1, 58-95.

Chapagain, A.K., Hoekstra, A.Y., Savenije, H.H.G., Gautam, R., 2006. The water footprint of cotton consumption: an assessment of the impact of worldwide consumption of cotton products on the water resources in the cotton producing countries. Ecological Economics 60, 186-203.

Chen, D.C., Lei, X.Y., Cao, W., Li, Y., 2012. Design and implementation of an irrigation decision support system for cotton in Xinjiang, China. Sensing Letters 10 (1-2), 459-464 (6 pp.).

Cholpankulov, E.D., Inchenkova, O.P., Paredes, P., Pereira, L.S., 2008. Cotton irrigation scheduling in Central Asia: model calibration and validation with consideration of groundwater contribution. Irrigation and Drainage 57, 1-17.

Dağdelen, N., Başal, H., Yılmaz, E., Gürbüz, T., Akçay, S., 2009. Different drip irrigation regimes affect cotton yield, water use efficiency and fiber quality in western Turkey. Agricultural Water Management 96, 111-120.

Darouich, H., Gonçalves, J.M., Pereira, L.S., 2007. Water saving scenarios for cotton under surface irrigation: analysis with the DSS SADREG. In: Lamaddalena, N. Boglioti, C., Todorovic, M., Scardigno, A. (Eds.), Water Saving in Mediterranean Agriculture \& Future Research Needs. Options Mediterranéennes, Série B, 56, vol. I, pp. 381-396.

Farahani, H.J., Izzi, G., Oweis, T.Y., 2009. Parameterization and evaluation of the aquacrop model for full and deficit irrigated cotton. Agronomy Journal 101, 469-476.

Fereres, E., Soriano, M.A., 2007. Deficit irrigation for reducing agricultural water use. Journal of Experimental Botany 58 (2), 147-159.

Galli, D., Morini, C., Di Terlizzi, B., 2010. Sustainable crop management model in Syrian strategic crops. The experience of the cooperation project rationalization of Ras El Ain irrigation systems. In: ISDA 2010, Montpellier, France.

Gonçalves, J.M., Pereira, L.S., 2009. A decision support system for surface irrigation design. Journal of Irrigation and Drainage Engineering - ASCE 135 (3), 343-356.

Gonçalves, J.M., Horst, M.G., Pereira, L.S., 2011. Furrow irrigation design with multicriteria analysis. Biosystems Engineering 109, 266-275.

Hole, F., 2009. Drivers of unsustainable land use in the semi-arid Khabur River Basin, Syria. Geography Research 47 (1), 4-14.

Hornbuckle, J.W., Christen, E.W., Faulkner, R.D., 2005. Use of SIRMOD as a quasi rea time surface irrigation decision support system. In: Zerger, A., Argent, R.M.(Eds.) MODSIM 2005. International Congress on Modelling and Simulation, Modelling and Simulation Society of Australia and New Zealand, pp. 217-223.

Horst, M.G., Shamutalov, S.S., Pereira, L.S., Gonçalves, J.M., 2005. Field assessment of the water saving potential with furrow irrigation in Fergana, Aral Sea Basin. Agricultural Water Management 7, 210-231.

Horst, M.G., Shamutalov, S.S., Gonçalves, J.M., Pereira, L.S., 2007. Assessing impacts of surge-flow irrigation on water saving and productivity of cotton. Agricultura Water Management 87 (2), 115-127.

Hunsaker, D.J., Clemmens, A.J., Fangmeier, D.D., 1998. Cotton response to high frequency surface irrigation. Agricultural Water Management 37, 55-74.

Janat, M., 2008. Response of cotton to irrigation methods and nitrogen fertilization: yield components, water use efficiency, nitrogen uptake, and recovery. Communications in Soil Science and Plant Analysis 39, 2282-2302.

Kamash, Z., 2012. Irrigation technology, society and environment in the Roman Near East. Journal of Arid Environment http://dx.doi.org/10.1016/j.jaridenv.2012.02.002.

Karam, F., Lahoud, R., Masaad, R., Daccache, A., Mounzer, O., Rouphael, Y., 2006 Water use and lint yield response of drip irrigated cotton to the length of irrigation season. Agricultural Water Management 85, 287-295.

MAAR, 2011. Land Use Balance. Department of Statistics and Planning, Ministry of Agriculture and Agrarian Reform, Damascus (in Arabic).

McCorriston, J., Weisberg, S., 2002. Spatial and temporal variation in Mesopotamian agricultural practices in the Khabur Basin, Syrian Jazira. Journal of Archaeological Science 29, 485-498.

Oweis, T.Y., Farahani, H.J., Hachum, A.Y., 2011. Evapotranspiration and water use of full and deficit irrigated cotton in the Mediterranean environment in northern Syria. Agricultural Water Management 98, 1239-1248.

Öztan, M., Axelrod, M., 2011. Sustainable transboundary groundwater management under shifting political scenarios: the Ceylanpinar Aquifer and Turkey-Syria relations. Water International 36 (5), 671-685.

Pedras, C.M., Pereira, L.S., Gonçalves, J.M., 2009. MIRRIG: a decision support system for design and evaluation of microirrigation systems. Agricultural Water Management 96 (4), 691-701. 
Pereira, L.S., Oweis, T., Zairi, A., 2002. Irrigation management under water scarcity. Agricultural Water Management 57 (3), 175-206.

Pereira, L.S., Teodoro, P.R., Rodrigues, P.N., Teixeira, J.L., 2003. Irrigation scheduling simulation: the model ISAREG. In: Rossi, G., Cancelliere, A., Pereira, L.S., Oweis, T., Shatanawi, M., Zairi, A. (Eds.), Tools for Drought Mitigation in Mediterranean Regions. Kluwer, Dordrecht, pp. 161-180.

Pereira, L.S., Paredes, P., Cholpankulov, E.D., Inchenkova, O.P., Teodoro, P.R., Horst, M.G., 2009. Irrigation scheduling strategies for cotton to cope with water scarcity in the Fergana Valley, Central Asia. Agricultural Water Management 96 (5), 723-735.

Pereira, L.S., Cordery, I., Iacovides, I., 2012. Improved indicators of water use performance and productivity for sustainable water conservation and saving. Agricultural Water Management 108, 39-51.

Pomerol, J.C., Romero, S.B., 2000. Multicriterion Decision in Management: Principles and Practice. Kluwer Acad. Publ., Dordrecht.

Richards, Q.D., Bange, M.P., Johnston, S.B., 2008. HydroLOGIC: an irrigation management system for Australian cotton. Agricultural Systems 98 (1), 40-49.

Roy, B., Bouyssou, D., 1993. Aide Multicritère: Méthodes et Cas. Economica, Paris.

Sadiddin, A., 2009. The foreseen impact of the recent policy reforms and other scenarios on water use in Syrian Arab Republic: the case of Al-Khabour Basin. Working Paper No. 46, NAPC, Damascus.

Sadiddin, A., Atiya, B., 2009. Analysis of agricultural production for selected crops: wheat, cotton and barley. Working Paper No. 44, NAPC, Damascus.
Shweih, R., 2006. Comparative advantages of cotton commodity chain. Working Paper No. 21, National Agricultural Policy Centre (NAPC), Damascus.

Smith, R.J., Raine, S.R., Minkevich, J., 2005. Irrigation application efficiency and deep drainage potential under surface irrigated cotton. Agricultural Water Management 71 (2), 117-130.

Solomon, K.H., 1984. Yield related interpretations of irrigation uniformity and efficiency measures. Irrigation Science 5 (3), 161-172.

Subramani, J., Martin, E.C., 2012. Effects of every furrow vs. every other furrow surface irrigation in cotton. Applied Engineering in Agriculture 28 (1), 39-42.

Thysen, I., Detlefsen, N.K., 2006. Online decision support for irrigation for farmers. Agricultural Water Management 86, 269-276.

Walker, W.R., 1998. SIRMOD - Surface Irrigation Modeling Software. Utah State University, Logan.

Walker, W.R., Skogerboe, G., 1987. Surface Irrigation: Theory and Practice. PrenticeHall, Inc., Englewood Cliffs, New Jersey.

Wichelns, D., Oster, J.D., 2006. Sustainable irrigation is necessary and achievable, but direct costs and environmental impacts can be substantial. Agricultural Water Management 86, 114-127.

Yazar, A., Sezen, S.M., Sesveren, S., 2002. LEPA and trickle irrigation of cotton in the Southeast Anatolia Project (GAP) area in Turkey. Agricultural Water Management 54, 189-203. 